\title{
Antimicrobial Resistance and Potential Probiotic Application of Enterococcus spp. in Sea Bass and Sea Bream Aquaculture
}

\author{
Ouissal Chahad Bourouni ${ }^{1}$, Monia El Bour ${ }^{1}$, \\ Pilar Calo-Mata ${ }^{2}$ and Jorge Barros-Velàzquez ${ }^{2}$ \\ ${ }^{1}$ Institut National des Sciences et Technologies de la Mer (INSTM), Tunis, \\ 2Department of Analytical Chemistry, Nutrition and Food Science, LHICA, \\ School of Veterinary Sciences, University of Santiago de Compostela, \\ 1Tunisia \\ 2Spain
}

\section{Introduction}

Microbial resistance to antibiotics is a world-wide problem in human and veterinary medicine. It is generally accepted that the main risk factor for the increase in the antibiotic resistance is an extensive use of antibiotics. In fact, for the last 50 years, high levels of antibiotics are commonly used for treatment and prevention of infectious diseases in humans and animals. This led to emergence and dissemination of resistant bacteria and resistance genes in wild populations (Bogaard \& Stobberingh 2000). The antimicrobial agents used in animal care are also significant, both in increasing resistance in animal pathogens, and in transmission of resistant bacteria from animals to humans. In part, this is due to the transfer of antimicrobial-resistant normal or commensal microflora of animals, via the food chain to humans. Several recent papers reported link between antibiotic use in food producing animals, emergence of antibiotic resistance in Salmonella, Escherichia coli, enterococci or Campylobacter in treated animals and transfer of these resistances to humans (or their resistance genes to human pathogens) via the food chain (Barton 2000; Angulo et al. 2004). However, less attention was paid to potential for antibiotic use in aquaculture industries to compromise human health. In addition to transfer of resistant bacteria through consumption of contaminated fish and shellfish, there is substantial risk of environmental contamination due to practice of using medicated feeds to treat whole pens or cages.

\section{Antibiotic resistance in aquaculture}

Aquaculture around the Mediterranean basin has increased significantly to satisfy the demand for seafood, which cannot be met by wild fisheries harvesting as this is currently in a state of decline because of over-fishing, pollution and marine habitat destruction. Recent reports of the United Nations Food and Agriculture Organization (FAO), noted approximately more than $290.10^{3}$ tons for the mainly species of marine fish farmed (sea bass and sea bream) and had previously estimated that half of the world's seafood demand will 
be met by aquaculture in 2020 (FAO, 2008). In Mediterranean aquaculture, the culture practices for most farmed fish species are mostly semi-intensive or intensive and a significant challenge to fish farming however is disease caused by bacteria such as Aeromonas sp., Vibrio sp., Pseudomonas sp. and Flavobacterium sp. Both prophylactic and therapeutic treatments utilize drug supplemented feeds to keep farmed fish free of diseases.

Antibiotics such as oxytetracycline (OTC) and quinolone such as oxolinic acid (OA) are the most widely used in Mediterranean aquaculture in feed (Rigos \& Troisi, 2005) and treatments discharge drugs directly into the marine environment, where they are relatively resistant to biodegradation. Rigos et al., 2004 found that $60-73 \%$ of the OTC and $8-12 \%$ of the OA administered to farmed sea bream were excreted with the faeces. Also, the results of ARMed (Antibiotic Resistance in the south-eastern Mediterranean) suggest existence of high resistances of bacteria particularly in the eastern region where the resistance in E. coli appears to be more important than in other Mediterranean countries.

Previous reports noted that resistance emergence result directly from infections treatment with antibacterial drugs (Sorum 1998, 1999) and therefore limited their value in control of bacterial diseases of fish (Smith et al., 1994), apart from any public health concerns.

Further, antibacterial drugs were shown to persist in animal tissues and in the sea, including the aquatic food chain (CIESM, 2004) and development of antibiotic resistance is direct consequence of drug pollution. Chelossi et al., 2003 found that antibiotics discharged through faeces or undigested feed, contributed to high incidences of quinolone, tetracyclin and penicillin-resistant benthic bacteria and caused a shift in structure of the benthic microbial assemblage next to fish farms. Moreover, a considerable increase in resistance to several antimicrobial drugs has been discovered in some species of Vibrio and Pseudomonas recovered from diseased farmed sea bream of south-western Spain (Zorilla et al., 2003).

In Turkey, bacteria isolated from sea bass (Dicentrarchus labrax) showed a multidrug resistance to trimethoprim-sulfamethoxazole, cephalothin, tetracyclin and streptomycin suggesting that fish farms act as a reservoir of multidrug-resistant pathogenic bacteria such as Pseudomonas and Vibrio (Matyar, 2007). Considering the frequent usage of anti-bacterial drugs in Mediterranean fish farming, and serious problems of their rapid increase in resistance and transfer to non-target microflora including human and animal pathogens, there is an urgent need for monitoring drug contamination in aquatic environment and thus, the need for alternative techniques replacing drugs with effective and inexpensive probiotics which became increasingly evident and necessary to avoid resistance in fish farming sites and antibiotic residues in fish flesh destined for human consumption.

In Tunisia, aquaculture fish industry was developed since 1989 and has highly increased during these last ten years and national production passed from 1566 tons in 2000 to 4468 tons in 2009 with an increase in number of aquatic farms multiplied by about five. The production statistics in 2009 noted more than 2800 tons for marine fish farming. Regarded as a strategic activity that can support the fishing sector, aquaculture benefits in Tunisia of a particular interest mainly for the most two marine species farmed sea bass (Dicentrarchus labrax) and sea bream (Sparus aurata), which were undertaken in almost private farms.

The evolution of antibiotic resistance of the main bacterial species of medical interest is subject to increased surveillance in Tunisia. Since 1999, the research laboratory on antibiotic 
resistance (LAB MDT-03) established a system for monitoring bacterial resistance to antibiotics (L'Antibio - Résistance en Tunisie or LART). It includes four hospitals regularly monitoring the epidemiology of major bacterial species of medical importance and antibiotic resistance data collected are used in development of recommendations to antibiotic therapy (Boutiba et al., 2007). However, the problem of antibiotic resistance is underestimated in animal production including aquaculture and studies related are scarced. A study of pathogens vibrios isolated from sea bass showed a multi-resistance of Vibrio alginolyticus and Vibrio parahaemolyticus for almost antibiotics used and sensitivity was only demonstrated for furazolidone and chloramphenicol (Bakhrouf et al., 1995). Bouamama et al., 2001 isolated several multiresistant bacteria from mussel Mytilus galloprovincialis with resistance profiles to 12 different antibiotics in Aeromonas hydrophila and Propioni acnes. Vibrio alginolyticus was isolated from internal organs of sea bream and sea bass reared in two fish farms located in Tunisian coast. Multi-drug resistance to antimicrobial agents was detected, all the 34 strains tested were resistant to ampicillin, 31 strains were resistant to nitrofurantoïne and 12 were resistant to tetracycline (Ben Kahla-Nakbi et al., 2006). The most recent study of Rezgui et al., (2010) showed abundance of antibiotic resistant bacteria isolated mainly from gills and intestinal tract of sea bream and sea bass which belong to several species of the genus Pseudomonas, Aeromonas, Vibrio and Enterobacteriaceae and were resistant essentially to tetracyclin and penicillin (antibiotics commonly used respectively in veterinary and human clinical).

\section{Probiotics as alternative to antibiotics in aquaculture}

The increasing problems associated with infectious diseases in fish, the frequent usage of drugs for treatment and prevention of these diseases and the rapid increase in resistance to these antibiotics represent major challenges for this source of food production worldwide. Thus, replacing drugs with effective and inexpensive probiotics was became increasingly evident and necessary to avoid resistance in fish farming sites and antibiotic residues in fish flesh destined for human consumption (Vershuere et al., 2000; Balcazar et al., 2006; Rengpipat et al., 2008).

\subsection{Probiotics: definition and principles}

The term, probiotic, simply means "for life", originating from the Greek words "pro" and "bios" (Gismondo et al., 1999). The most widely quoted definition was made by Fuller (1989). He defined a probiotic as "a live microbial feed supplement which beneficially affects the host animal by improving its intestinal balance". This definition is still widely referred to, despite continual contention with regard to the correct definition of the term. Current probiotic applications and scientific data on mechanisms of action indicate that non-viable microbial components act in a beneficial manner and this benefit is not limited just to the intestinal region (Salminen et al., 1999). Besides, based on the intricate relationship an aquatic organism has with the external environment when compared with that of terrestrial animals, the definition of a probiotic for aquatic environments needs to be modified. Verschuere et al. (2000a) suggested the definition "a live microbial adjunct which has a beneficial effect on the host by modifying the host-associated or ambient microbial community, by ensuring improved use of the feed or enhancing its nutritional value, by enhancing the host response towards disease, or by improving the quality of its ambient environment". 


\subsection{Different modes of action}

Several studies have demonstrated certain modes of probiotic action in effect in the aquatic environment. Bairagi et al. (2002) assessed aerobic bacteria associated with the gastrointestinal tract (GIT) of nine freshwater fish. They determined that selected strains produced digestive enzymes, thus facilitating feed utilization and digestion. Ramirez \& Dixon (2003) reported on the enzymatic properties of anaerobic intestinal bacteria isolated from three fish species, showing the potential role a probiotic could play. In the paper of Bairagi et al. (2004) the benefit of adding B. subtilis and B. circulans to the diet of rohu, Labeo rohita, was shown. In the search to replace fish meal with leaf meal in fish feed, they found that addition of the two fish intestinal Bacillus spp. increased performance as judged by several factors (growth, feed conversion ratio, and protein efficiency ratio). They attributed this to the extracellular cellulolytic and amylolytic enzyme production by the bacteria. Although competition for adhesion sites has been widely suggested as a mode of action, there is little evidence in the literature to demonstrate this. Although for not direct attachment competition, Yan et al. (2002) demonstrated that production of antibiotic substances by two seaweed-associated Bacillus sp. was dependent on biofilm formation by the bacteria. This study highlighted a factor which might be important for some bacteria to be effective probiotics, i.e. surface attachment. Such observation concurred with Fuller's (1989) definition of a probiotic, i.e. the requirement for GIT colonization. It has been proposed that the mechanism of competitive exclusion for attachment sites could be given a distinct advantage via addition of probiotic bacteria during the initial egg fertilization steps of larviculture, thereby "getting in there first" (Irianto and Austin, 2002a).

Several studies have attributed a probiotic effect to competition for energy sources (Rico Mora et al., 1998; Verschuere et al., 1999; Verschuere et al., 2000b). Beneficial growth and survival was found in Artemia sp. pre-exposed to nine strains of bacteria before challenge with $V$. proteolyticus (Verschuere et al., 1999). It was concluded that the effect was not caused by extracellular products, but required the live bacterial cell. Although it was not specifically tested, they hypothesized that the protective effect probably resulted from competition for energy sources and for adhesion sites.

Itami et al. (1998) found that addition of Bifidobacterium thermophilum derived peptidoglycan to kuruma shrimp increased significantly their survival when they were challenged with $V$. penaeicida. They attributed this to an immunostimulatory effect, as the phagocytic activity of shrimp granulocytes was significantly higher in the treated shrimp compared with those of the control animals. Gullian et al. (2004) tested immunostimulation by a live Vibrio sp. (P62) and Bacillus sp. (P64), using V. alginolyticus as a positive control. They concluded that P64 and $V$. alginolyticus were immunostimulants. A review by Smith et al. (2003) provided important information on the potential problems associated with immunostimulants in crustacean aquaculture. They argued that the prolonged use of immunostimulants was in fact detrimental to the host and that much more research was needed before their use during critical periods could be considered safe.

Competition for iron has been reported as an important factor in marine bacteria (Verschuere et al., 2000a). Iron is needed by most bacteria for growth, but is generally limited in the tissues and body fluids of animals and in the insoluble ferric Fe3+ form (Verschuere et al., 2000a). Iron-binding agents, siderophores, allow acquisition of iron suitable for microbial growth. Siderophore production is a mechanism of virulence in some 
pathogens (Gram et al., 1999). Equally, a siderophore producing probiotic could deprive potential pathogens of iron under iron limiting conditions. This was shown by Gram et al. (1999), who found that a culture supernatant of Pseudomonas fluorescens, grown in ironlimited conditions, inhibited growth of $V$. anguillarum, whereas the supernatant from ironavailable cultures did not.

Possibly the most studied mode of probiotic action in aquatic animals is the production of inhibitory substances. Currently, there are four methods commonly employed to screen for inhibitory substances in vitro; the double layer method, the well diffusion method, the crossstreak method, and the disc diffusion method. All methods are based on the principle that a bacterium produces extracellular substance inhibitor to itself or another bacterial strain (the indicator). The inhibitory activity is displayed by growth increase of the producer culture in agar medium.

This in vitro screening method has identified very good probiotics in aquaculture (Irianto \& Austin, 2002b; Lategan and Gibson, 2003; Vaseeharan et al., 2004; Lategan et al., 2004a,b), with two major limitations for this approach. The first is that other modes of probiotic activity (e.g. immunostimulation, digestive enzymes production, competition for attachment site, or nutrients) will not be expressed in the laboratory on agar plate and, hence, a major source of potential beneficial action will be overlooked. The second drawback is that positive results in vitro fail to determine the real in vivo effect.

\subsection{Developing probiotics for aquaculture}

It has been widely published that a probiotic must possess certain properties (Verschuere et al., 2000a). These properties were proposed in order to aid in correct establishment of new, effective and safe products and included:

1. The probiotic should not be harmful to the host it is desired for,

2. It should be accepted by the host, e.g. through ingestion and potential colonization and replication within the host,

3. It should reach the location where the effect is required to take place,

4. It should actually work in vivo as opposed to in vitro findings,

5. It should preferably not contain virulence resistance genes or antibiotic resistance genes.

The future application for probiotics in aquaculture looks bright. There is an ever-increasing demand for aquaculture products and a similar increase in the search for alternatives to antibiotics. The field of probiotics intended for aquacultured animals is now attracting considerable attention and a number of commercial products are available.

\subsection{Probiotic strains studied in aquaculture}

Most probiotics proposed as biological control agents in aquaculture belong to the lactic acid bacteria (Lactobacillus and Carnobacterium), although other genera or species have also been studied, belonging to the genus Vibrio, to the genus Bacillus, or to the genus Pseudomonas, and also Aeromonas and Flavobacterium (Table 1).

Within probiotic group, lactic acid bacteria (LAB) have been recognized for their fermentative ability as well as their health and nutritional benefits since they exert strong 
antimicrobial activities against many pathogenic microorganisms and were considered as harmless bacteriocin-producing strains which may act antagonistic against fish pathogens (Maugin \& Novel, 1994; Ringo \& Gatesoupe, 1998). Moreover, LAB were signalled as competing for nutrients or space with spoiling microorganisms due to their ability to produce organic acids, hydrogen peroxide, diacetyl and bacteriocins and therefore should be of applied interest for marine fish and shellfish food bio-preservation (Franz C. et al., 2007).

\begin{tabular}{|c|c|c|c|}
\hline Animals tested & Potential probiotic & $\begin{array}{l}\text { Pathogen tested or type of study } \\
\text { conducted }\end{array}$ & Test method \\
\hline Gilthead sea bream & $\begin{array}{l}\text { Cytophaga sp., Roseobacter sp., Ruergeria sp., } \\
\text { Paracoccus sp.,A. sp., Shewanella sp. }\end{array}$ & Natural larval survival study & In vivo \\
\hline Gilthead sea bream & V. spp., Micrococcus sp. & L. anguillarum & In vitro and in vivo \\
\hline Atlantic cod & Carnobacterium divergens & V. anguillarum & In vitro and in vivo \\
\hline Atlantic cod & Carnobacterium divergens & V. anguillarum & In vitro and in vivo \\
\hline Atlantic salmon & Lactobacillus plantarum & A. salmonicida & In vitro and in vivo \\
\hline Atlantic salmon & Carnobacterium sp. (K1) & V. anguillarum, A. salmonicida & In vitro and in vivo \\
\hline Atlantic salmon & Ps. fluorescens & A. salmonicida & In vitro and in vivo \\
\hline $\begin{array}{l}\text { Atlantic salmon, } \\
\text { rainbow trout }\end{array}$ & Carnobacterium sp. & $\begin{array}{l}V . \text { anguillarum, } V . \text { ordalii, } \\
\text { Y. ruckeri, } A \text {. salmonicida }\end{array}$ & In vitro and in vivo \\
\hline Eel & $\begin{array}{l}\text { Commercial product: Cernivet }{ }^{\circledR} L B C \\
\text { (Ent. Faecium SF68), Toyocerin } ®(\text { B. toyoi) }\end{array}$ & Ed. tarda & In vivo \\
\hline Eel. & A. media & Saprolegnia sp & In vitro and in vivo \\
\hline Eel & A. media & Saprolegnia parasitica & In vivo \\
\hline Goldfish & Dead cells of A. hydrophila & A. salmonicida & In vivo \\
\hline Indian major carp & B. subtilis & A. hydrophila & In vivo \\
\hline Nile tilapia & $\begin{array}{l}\text { Str. faecium, Lactobacillus acidophilus, } \\
\text { Sacc. cerevisiae }\end{array}$ & Growth study & In vivo \\
\hline Pollack & $\begin{array}{l}\text { Commercial product: Bactocell (Pediococcus } \\
\text { acidilactici), Levucell (Sacc. cerevisiae) }\end{array}$ & $\begin{array}{l}\text { Pollack growth study using } \\
\text { enriched Artemia }\end{array}$ & In vivo \\
\hline Rainbow trout & Ps.fluorescens & $V$. anguillarum & In vitro and in vivo \\
\hline Rainbow trout & Lactobacillus rhamnosus & A. salmonicida ssp. salmonicida & - \\
\hline Rainbow trout & Ps. spp. & (furunculosis) & \\
\hline Rainbow trout & A. hydrophila, V. fluvialis, Carnobacterium sp. & V. anguillarum & In vitro and in vivo \\
\hline Rainbow trout & $\begin{array}{l}\text { Dead cells of } A . \text { hydrophila, } V . \text { fluvialis, } \\
\text { Carnobacterium sp. }\end{array}$ & $\begin{array}{l}\text { A. salmonicida } \\
\text { A. salmonicida }\end{array}$ & $\begin{array}{l}\text { In vitro and in vivo } \\
\text { In vivo }\end{array}$ \\
\hline Rainbow trout & Lactobacillus rhamnosus & Immune enhancement paper & In vivo \\
\hline Rainbow trout & $\begin{array}{l}\text { Commercial product: BioPlus } 2 B \text { (B. subtilis, } \\
\text { B. licheniformis) }\end{array}$ & $\begin{array}{l}\text { Y. ruckeri } \\
\text { Natural immunostimulation measured }\end{array}$ & In vivo \\
\hline Rainbow trout & Lactobacillus rhamnosus & Prevention of vertebral column & In vivo \\
\hline Rainbow trout & Pediococcus acidilactici, Sacc. boulardii & compression syndrome & In vivo \\
\hline Rainbow trout & A. sobria & L. garvieae, Str. iniae & In vivo \\
\hline Rainbow trout & Lactobacillus rhamnosus & Natural immunostimulation measured & In vivo \\
\hline Rohu & B. circulans, B. subtilis & Digestive enzyme study & In vivo \\
\hline Sea bass & Debaryomyces hansenii, Sacc. cerevisiae & Digestive enzyme study & In vivo \\
\hline Senegalese sole & V.spp., Ps. spp., Micrococcus sp. & $V$. harveyi & In vitro and in vivo \\
\hline Silver perch & A. media & Saprolegnia sp. & In vivo \\
\hline Tilapia & Commercial product: Alchem Poseidon, Korea & Ed. $\operatorname{tarda}$ & In vivo \\
\hline Turbot & 2 unidentified marine bacteria & GIT colonization study & In vivo \\
\hline Turbot & Marine bacteria & Natural survival study & In vivo \\
\hline Turbot & Roseobacter spp., V.spp. & $\begin{array}{l}\text { V. anguillarum, V. splendidus, Psalt. } \\
\text { sp. }\end{array}$ & In vitro and in vivo \\
\hline
\end{tabular}

Table 1. Summary of research towards probiotics for finfish

The LAB bacteriocin producer widespread in nature, and were isolated from several sources: dairy products, fermented sausages, vegetables, sillage, and mammalian gastrointestinal tract (Laukova et al., 1993; Kato et al., 1994; Giraffa, 1995; Ennahar et al.,1998). Recently, bacteriocin producing LAB were efficiently tested in attempt to improve aquatic 
environment for both shrimp and fish aquaculture (Calo-Mata P et al., 2007; Chae-Woo et al., 2009). Among them, bacteria belonging to the genus Enterococcus are primarily associated with the indigenous human and animal gastrointestinal flora and are widely distributed, being found in air, water, sewage, soil and vegetation (J. Lukasova \& A. sustackova, 2003). Although certain Enterococcus spp. have recently been associated with human nosocomial infections (Murray, 1998), a wide variety of enterococcal strains are increasingly being used as probiotics owing to their contribution to the healthy microflora of human mucosal surfaces. They have also been introduced into animal foods owing to their contribution to the health of farmed animals and as biological control agents in aquaculture (Calo-Mata P. et al., 2007).

\section{Probiotic development in aquaculture farming in Tunisia}

In Tunisia, fish farming of the two species sea bass (Dicentrarchus labrax) and gilthead sea bream (Sparus aurata) has significantly increased since a great benefit for such aquaculture which was threatened by microbial infections causing high mortalities at larval stages, and therefore decrease in farmed fish production. In addition, widespread use of antibiotics created an ecological problem for coastal ecosystems due to emergence of antibiotic resistant pathogen bacteria (Bouamama, 2001; Dellali, 2001; El Bour et al., 2001). Therefore, selection and use of probiotic bacteria capable of inhibiting pathogenic bacteria in sustainable way without ecosystem alteration would be a useful for specific farming problems. In this scope, for several years the INSTM team in Tunisia, in collaboration with the Department of Analytical Chemistry, Nutrition and Food Science, from the University of Santiago de Compostela in Spain were focusing in isolation and characterization of probiotic group, lactic acid bacteria (LAB) which were recognized for their fermentative ability as well as their health and nutritional benefits.

The study aimed to investigate the occurrence and antibiotic resistance profiles of Enterococcus spp. associated to the skin and the gastrointestinal tract of farmed sea bass and sea bream, the main fish species with high economic value cultured in Mediterranean aquaculture. This was accomplished by phenotypic and genotypic analysis, the latter including 16S rRNA sequencing and RAPD-PCR analysis. Besides, and with a view to perform a preliminary screening of potential probiotic LAB, the strains were investigated in their ability to produce antibacterial compounds against spoilage and pathogenic bacteria.

\subsection{Methodology}

Gilthead sea bream (Sparus aurata) and European sea bass (Dicentrarchus labrax) were collected from a fish farm in Hergla (Aquaculture Tunisiènne, Monastir, Tunisia). Skin patches were excised and the intestinal content was removed by dissecting the fish, removing the intestine and squeezing out the contents. Eighty four LAB strains were then isolated and investigated. The phenotypic characterization of bacterial isolates was studied to determine their colony morphology, cell morphology, motility, Gram stain and the production of cytochrome oxidase and catalase. The phenotypic identification of LAB strains was carried out by means of miniaturized API $50 \mathrm{CH}$ biochemical tests (BioMérieux, Marcy L'Etoile, France). The results of the identification tests were interpreted using the APILAB PLUS software (BioMérieux). 
Production of antibacterial activities was investigated, against a range of 39 pathogenic and spoilage microorganisms (Table2), to select potential producer strains. Detection of bacteriocin activity in LAB strains was screened by means of a standardized agar disk diffusion method.

\begin{tabular}{|c|c|c|c|}
\hline Code & Genus & Species & Origin \\
\hline AmH01 & $\overline{\text { Aeromonas }}$ & hydrophila & ATCC 7966 \\
\hline $\mathrm{BaC} 23$ & Bacillus & cereus & ATCC 14893 \\
\hline $\mathrm{BaP} 31$ & Bacillus & pumilus & ATCC 7061 \\
\hline BaS05 & Bacillus & Subtilis ssp. Spizizenii & ATCC 6633 \\
\hline ВxT01 & Brochotrix & thermosphacta & ATCC 11509 \\
\hline $\mathrm{CbD} 21$ & Carnobacterium & divergens & ATCC 35677 \\
\hline CbM01 & Carnobacterium & maltaromaticum & LHICA collection \\
\hline EbA01 & Enterobacter & aerogenes & ATCC 13048 \\
\hline EbC11 & Enterobacter & cloacae & ATCC 13047 \\
\hline HaA02 & Hafnia & alvei & ATCC 9760 \\
\hline $\mathrm{K} 1 \mathrm{O} \times 11$ & Klebsiella & oxytoca & ATCC 13182 \\
\hline K1P02 & Klebsiella & planticola & ATCC 33531 \\
\hline $\mathrm{K} 1 \mathrm{Pn} 21$ & Klebsiella & Pneumoniae ssp. pneumoniae & ATCC 10031 \\
\hline Lb30A & Lactobacillus & saerimneri & LHICA collection \\
\hline MoM02 & Morganella & morganii ssp. morganii & ATCC $8076 \mathrm{H}$ \\
\hline PhD11 & Photobacterium & damselae & ATCC 33539 \\
\hline PrM01 & Proteus & mirabilis & ATCC 14153 \\
\hline PrP11 & Proteus & penneri & ATCC 33519 \\
\hline PrV21 & Proteus & vulgaris & ATCC 9484 \\
\hline PsF12 & Pseudomonas & fluorescens & ATCC 13525 \\
\hline PsFr51 & Pseudomonas & fragi & ATCC 4973 \\
\hline PsG21 & Pseudomonas & gessardii & LHICA collection \\
\hline SrM53 & Serratia & marcescens ssp. marcescens & ATCC 274 \\
\hline SyE21 & Staphylococcus & epidermidis & ATCC 35983 \\
\hline SyX11 & Staphylococcus & xylosus & ATCC 29971 \\
\hline StM03 & Stenotrophomonas & maltophilia & ATCC 13637 \\
\hline 59 & Staphylococcus & aureus & ATCC 9144 \\
\hline 4521 & Staphylococcus & aureus & ATCC 35845 \\
\hline 4032 & Lysteria & monocytogenes & NCTC 11994 \\
\hline 1112 & Lysteria & monocytogenes 1112 & LHICA collection \\
\hline CI34.1 & Pseudomonas & anguilliseptica & Seabream* \\
\hline ACR5.1(AS) & Aeromonas & salmonicida & Turbot* \\
\hline CI52.1(VCI) & Vibrio & anguillarum & Seabream* \\
\hline ACC 30.1 & Photobacterium & damselae ssp. piscida & Sole* \\
\hline V62 & Vibrio & anguillarum & Seabream** \\
\hline VF & Vibrio & anguillarum & Seabass $* * *$ \\
\hline $\mathrm{AF}$ & Aeromonas & salmonicida & Seabass $* * *$ \\
\hline V90.11.287(V287) & Vibrio & anguillarum & Seabass $* * * *$ \\
\hline $\mathrm{AH} 2$ & Pseudomonas & fluorescens & Lates niloticus $* * * *$ \\
\hline
\end{tabular}

* Strains provided by Pr. J. L. Romalde (Spain). ** Strain provided by Pr. G. Breuil (France). *** Strains provided by Pr. J. C. Raymond (France). ${ }^{* * *}$ Strains provided by Pr. L. Gram (Denmark).

Table 2. Pathogenic and spoilage indicator microorganisms used to test the antibacterial activities of LAB isolates.

Genetic characterization of producer LAB strains was then performed by PCR targeted to the 16S rRNA gene using the universal set of primers: p8FPL (forward: 5' AGTTTGATCCTGGCTCAG-3') and p806R (reverse: 5'-GGACTACCAGGGTATCTAAT-3'), that yield a $800 \mathrm{bp}$ PCR product of the 16S rRNA gene. The PCR products were purified and sequenced. The sequences were compared with others present in GenBank database. 
Further genetic characterization of LAB isolates was performed by RAPD-PCR using primers M13 (5’-GAGGGTGGCGGTTCT-3’) (Andrighetto et al., 2004). To check reproducibility, all PCR assays were performed in triplicate. Each reaction we included a tube without template DNA as a negative control.

The antibacterial sensitivity was determined by the agar diffusion method according to Chabbert (1982), using 16 antibiotics that were selected as representative of different classes of antimicrobial agents relevant in human and animal medicine (Penicillin G, Amoxicillin, Oxacilin, Cefoxitin, Ceftriaxon, Streptomycin, Tobramycin, Neomycin, Chloramphenicol, Tetracyclin, Oleandomycin, Nitrofurantoin, Trimethoprim-Sulphonamid, Rifampicin, Oxolinic acid and also Vancomycin). Based on the zones of inhibition a qualitative report of "susceptible", "intermediate" or "resistant" can be determined for the tested bacteria according to French national guidelines (Comité de l'Antibiogramme de la Société Française de Microbiologie, 1996).

\subsection{Results and discussion}

Eighty four strains of LAB were isolated from both gastrointestinal content and skin of fish studied. All isolates were Gram-positive, catalase-negative, facultatively anaerobic and nonmotile chain-forming cocci. They were tested for assaying inhibitory production against 39 Gram-positives and Gram-negatives bacteria, including pathogenic bacteria in aquaculture and others spoilage bacteria. 58 strains (69\%) exhibited inhibitory activity against a large number of the indicator organisms investigated. Greater inhibition was observed against L. monocytogenes, S. aureus, A. hydrophila, A. salmonicida, V. anguillarum and Carnobacterium strains in comparison with the remaining indicators. The diameters of the inhibition halos were within the $7.5-18 \mathrm{~mm}$ range. Thus, we selected 35 highly producing strains that generated inhibitory zones with diameters between 12 and $18 \mathrm{~mm}$.

The results allowed the classification of the strains as belonging to the species E. faecium (29 strains) and E. sanguinicola (6 strains) (paper under process) (Table3). Other studies, previously mentioned, also showed that the skin and gastrointestinal tract of various fish species contains lactic acid bacteria which produce antibacterial compounds able to inhibit the growth of several micoorganisms (Ringo 1999; Spanggaard B. et al., 2001; Rengpipat S. et al., 2008; Vijayabaskar P \& Somasundaram S. T., 2008; Ringo, 2008).

According to the results obtained, all the strains tested were resistant to at least three different antibiotics. The frequency of resistance to the various antimicrobials for all bacteria is presented in Fig. 1. Differences of resistance rates were noted for amoxicillin, oxacillin, cephalosporins (cefoxitin, ceftriaxon), aminosids (streptomycin, tobramycin and neomycin), macrolids (oleandomycin) and oxolinic acid. In contrast, phenicol, tetracyclin, rifampicin and trimethoprim-sulphamid were the most active antibiotics against the majority of the bacterial isolates (fig1).

In fact, more than half $(64.8 \%)$ of all the isolates were found to be resistant to amoxicillin and $71.4 \%$ were resistant to oleandomycin, $78.1 \%$ to ceftriaxon, $80.1 \%$ to streptomycin and $85 \%$ to cefoxitin. Oxacillin resistance was found in $92.5 \%$ of the isolates and tobramycin and oxolinic acid resistance in $94.2 \%$. Resistance to neomycin was found in $98.3 \%$ of the isolates. Resistance to chloramphenicol and trimethoprim-sulphamide was detected in $5.1 \%$ and $2.2 \%$ of the isolates respectively, $8 \%$ of the isolates were found to be resistant to tetracyclin. Resistance to rifampicin was seen in $16.9 \%$ of the isolates 


\begin{tabular}{|c|c|c|c|c|}
\hline Strains & Fish & Organ & Identification & Accession number \\
\hline UPAA 1 & Sea bass & GIT & Enterococcus sanouinicola & GU460379 \\
\hline UPAA 4 & Sea bass & GIT & Enterococcus faecium & GU460381 \\
\hline UPAA 7 & Sea bass & Skin & Enterococcus faecium & GU460383 \\
\hline UPAA 11 & Sea bream & GIT & Enterococcus faecium & HQ450696 \\
\hline UPAA 15 & Sea bass & Skin & Enterococcus faecium & GU460385 \\
\hline UPAA 23 & Sea bass & GIT & Enterococcus faecium & GU460388 \\
\hline UPAA 24 & Sea bass & GIT & Enterococcus faecium & GU460389 \\
\hline UPAA 25 & Sea bass & GIT & Enterococcus faecium & GU460390 \\
\hline UPAA 31 & Sea bass & Skin & Enterococcus faecium & GU460394 \\
\hline UPAA 32 & Sea bass & GIT & Enterococcus faecium & GU460395 \\
\hline UPAA 33 & Sea bass & GIT & Enterococcus sanguinicola & GU460396 \\
\hline UPAA 34 & Sea bream & Skin & Enterococcus faecium & HQ450701 \\
\hline UPAA 35 & Sea bream & GIT & Enterococcus faecium & HQ450702 \\
\hline UPAA 37 & Sea bass & GIT & Enterococcus faecium & GU460398 \\
\hline UPAA 39 & Sea bream & GIT & Enterococcus faecium & HQ450704 \\
\hline UPAA 40 & Sea bream & GIT & Enterococcus faecium & HQ450705 \\
\hline UPAA 44 & Sea bream & Skin & Enterococcus faecuim & HQ450706 \\
\hline UPAA 45 & Sea bream & GIT & Enterococcus faecuim & HQ450707 \\
\hline UPAA 53 & Sea bass & GIT & Enterococcus faecium & GU460402 \\
\hline UPAA 54 & Sea bass & GIT & Enterococcus faecium & GU460403 \\
\hline UPAA 56 & Sea bass & Skin & Enterococcus faecium & GU460404 \\
\hline UPAA 57 & Sea bass & Skin & Enterococcus sanguinicola & GU460405 \\
\hline UPAA 58 & Sea bass & Skin & Enterococcus faecium & GU460406 \\
\hline UPAA 63 & Sea bass & GIT & Enterococcus faecium & GU460409 \\
\hline UPAA 71 & Sea bream & GIT & Enterococcus sanguinicola & HQ450716 \\
\hline UPAA 80 & Sea bass & GIT & Enterococcus faecium & GU460416 \\
\hline UPAA 83 & Sea bass & Skin & Enterococcus faecium & GU460415 \\
\hline UPAA 85 & Sea bream & GIT & Enterococcus faecium & HQ450721 \\
\hline UPAA 89 & Sea bream & GIT & Enterococcus faecium & HQ450724 \\
\hline UPAA 105 & Sea bass & GIT & Enterococcus faecium & GU460417 \\
\hline UPAA 110 & Sea bream & GIT & Enterococcus faecium & HQ450730 \\
\hline UPAA 111 & Sea bass & Skin & Enterococcus faecium & GU460420 \\
\hline UPAA 113 & Sea bass & GIT & Enterococcus sanguinicola & GU460421 \\
\hline UPAA 114 & Sea bass & GIT & Enterococcus faecium & GU460422 \\
\hline UPAA 116 & Sea bass & Skin & Enterococcus sanguinicola. & GU460423 \\
\hline
\end{tabular}

Table 3. Antibacterial producing isolates 


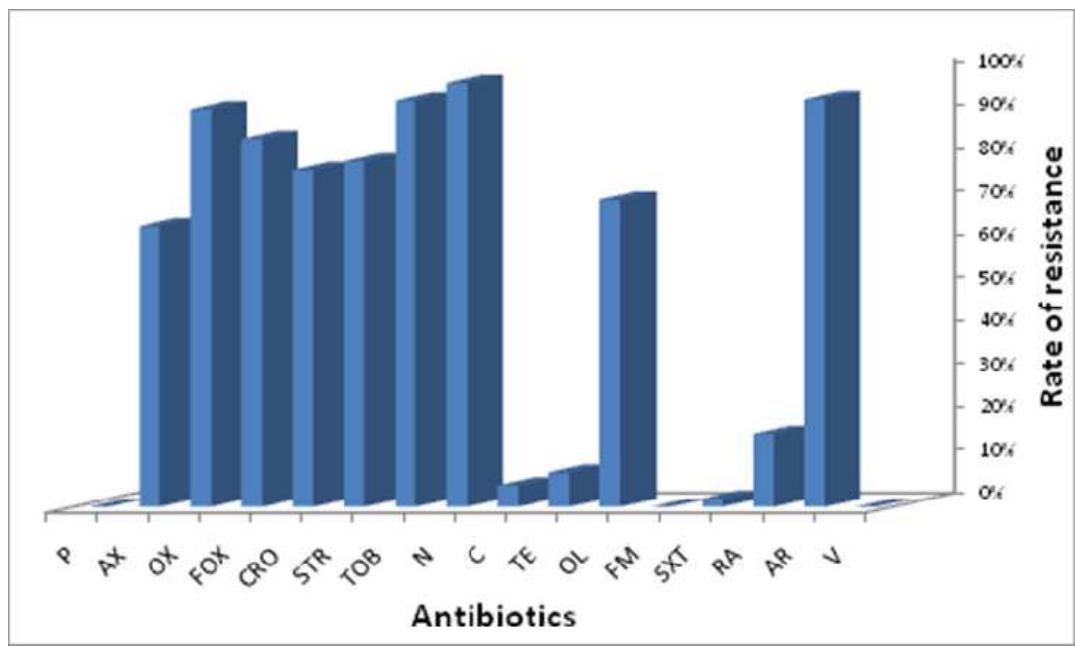

P: penicillin G; Ax: amoxicillin; Ox: oxacillin; Fox: cefoxitin; Cro: ceftriaxon; Str: streptomycin; Tob: tobramycin; N: neomycin; C: chloramphenicol; Te: tetracyclin; Ol: oleandomycin; Fm: furans; Sxt: trimethoprim-sulphamide; Ra: rifampicin; Ar: oxolinic acid; V: vancomycine.

Fig. 1. Profiles of resistance obtained for the different enterococci isolates against the 16 antimicrobial agents tested.

Interestingly, all the strains were sensitive to vancomycin, penicillin and furans and were not haemolytic.

Enterococci have been known to be resistant to most antibiotics used in clinical practice. Multidrug-resistant and vancomycin-resistant enterococci are commonly isolated from humans, animal sources, aquatic habitats, agricultural run-off which indicates their ability to enter the human food chain (Rice et al., 1995). They are naturally resistant to cephalosporins, aminoglycosides and clindamycin and may also be resistant to tetracyclins and erythromycin. They are intermediate sensitive to penicillin and ampicillin and glycopeptides. The strains that produce $\beta$-lactamase are rare and Vancomycin-resistant enterococci (VRE) are emerging as a global threat to public health.

Enterococci are known to acquire antibiotic resistance with relative ease and to be able to spread these resistance genes to other species (Kuhn et al., 2000). Enterococcus faecalis has been reported to transfer plasmids harbouring antibiotic-resistance traits to other enterococci and to Listeria monocytogenes in water treatment plants (Marcinek et al., 1998). Enterococcus faecium conjugative transposons can be transferred from animal bacteria to human ones. Such conjugative trasposons can also transfer vancomycin resistance to Staphylococcus aureus, streptococci and lactobacilli.

The extremely high level of antibiotic resistance observed in these bacteria has made them feared infectious agents in intensive care wards. Possible pathogenicity factors like hemolysins have been described. The most important species are E. faecalis and E. faecium, the first being more common in human illnesses, the second one (though less common in human infections) may pose a larger resistance threat (Huycke et al., 1998). 
In both species, the evolutionary development of resistance has been attributed to the possession of broad host range and extremely mobile genetic elements like conjugative plasmids and transposons. The molecular details of the structures and functions of these elements are fairly well studied and becoming understood (Clewell et al., 1995; Marra \& Scott 1999). It is noteworthy that transcription of the transfer functions of Tn916 requiring excission of the element is dramatically increased in the presence of tetracyclin (Celli \& Trieu-Cuot 1998).

Therefore, antibiotic resistance, notably to vancomycin, and the presence of haemolysins as an indicator of potential pathogenecity, must be evaluated in these microorganisms, before they can be used as probiotics and/or food additives.

The antimicrobial spectra observed for the Enterococcus species isolated included several genera indicating a broad spectrum of activity against Gram-positive but also Gramnegative pathogenic and spoilage organisms. A number of earlier studies have also shown that several marine bacteria produce inhibitory substances that inhibit bacterial pathogens in aquaculture systems (Nogami \& Maeda, 1992; Austin et al., 1995; Rengpipat et al., 1998; Gram et al., 1999; Chahad et al., 2007). The use of such bacteria to inhibit pathogens by release of antimicrobial substances is now gaining importance in fish farming as a better and more effective alternative than administering antibiotics to manage the health of these organisms (Vijayan et al., 2006). Spanggaard et al. (2001) reported that this antagonism was the most influential factor preventing the establishment of the exogenous bacteria and indicates that the antagonistic part of an indigenous flora may offer a significant contribution to the control of unwanted (pathogenic) bacteria.

LAB isolated from the same environment on which they will be further used as bio-control cultures, ensure that these LAB strains are well ecological adapted. This fact is an important factor for their effectiveness as natural antimicrobial agents. The local results suggest the potential usefulness of the inhibitory-producing strains isolated from fish, as probiotics in aquaculture, in order to prevent bacterial infections caused by A. salmonicida, A. hydrophila and $V$. anguillarum which are the most common pathogenic bacteria isolated from the marine environment, causing high mortalities of fish and shellfish. Their inhibitory activities show some properties which make it potentially remarkable food preservatives.

\section{Conclusion}

In comparison with studies on impact of antibio-resistance on terrestrial food producing animals, those related to marine aquaculture enterprises still scarced. The present study supports the view that there is a risk of transfer of resistant bacteria to humans from consumption of aquaculture products. In Tunisian field, although there are no products registered for use in aquaculture, antimicrobial resistance resistance is present in isolates from aquaculture..

The extent of the resistance found and in particular the significant levels of multiple resistance are of concern. Follow-up studies are required to investigate the extent of antibiotic use in Tunisian aquaculture farms and environments and to determine the molecular basis of antimicrobial resistance to the different antibiotics, the potential for transfer of resistance genes from aquaculture isolates to human pathogens, some assessment 
of the risk of transfer of resistant organisms (or genes) to humans via food chain and the threats imposed by environmental contamination with antibiotic resistant bacteria.

The highly antibacterial producing Enterococcus strains isolated from both sea bream and sea bass which inhibit growth of pathogenic and spoiling bacteria should have a potential practical interest and offer a natural means for simultaneous application as probiotics and/or for preventing the development of Listeria in food stuffs.

\section{References}

Andrighetto, C.; Knijif E.; Lombardi, A.; Vancanneyt, M.; Kersters, K.; Swings, J. \& Dellaglio F (2004). Phenotypic and genetic diversity of enterococci isolated from Italian cheeses. Journal of Dairy Research, Vol.68, pp.303-316

Angulo, F. J.; Nargund, V. N. \& Chiller, T. C. (2004). Evidence of an Association Between Use of Anti-microbial Agents in Food Animals and Anti-microbial Resistance Among Bacteria Isolated from Humans and the Human Health Consequences of Such Resistance. Journal of Veterinary Medecine, Vol. 51, pp.374-379

Austin, B.; Stuckey, L.F.; Robertson, PAW.; Effendi, I. \& Griffith, DRW. (1995). A probiotic strain of Vibrio alginolyticus effective in reducing diseases caused by Aeromonas salmonicida,Vibrio anguillarum and Vibrio ordalii. Journal of Fish Diseases, Vol.18, pp.93-96

Bairagi, A.; Sakar Ghosh; K., Sen; S.K. \& Ray, A.K. (2002). Enzyme producing bacterial flora isolated from fish digestive tracts. Aquaculture International, Vol.10, pp.109-121

Bairagi, A.; Sarkar Ghosh, K.; Sen, S.K. \& Ray, A.K. (2004). Evaluation of the nutritive value of Leucaena leucocephala leaf meal, inoculated with fish intestinal bacteria Bacillus subtilis and Bacillus circulans in formulated diets for rohu, Labeo rohita (Hamilton) fingerlings. Aquaculture Research, Vol. 35, pp. 436-446

Bakhrouf, A. ; Ben Ouada, H. \& Oueslati, R. (1995). Essai de traitement des vibrioses du loup Dicentrarchus labrax dans une zone de pisciculture, à Monastir, Tunisie. Marine Life, Vol.5, pp. 47-54

Balcàzar, JL.; de Blas, I.; Ruiz-Zarzuela, I.; Cunningham, D., Vendrell, D. \& Muuzquiz, JL. (2006). The role of probiotics in aquaculture. Veterinary Microbiology, Vol. 114, pp.173-186

Barton, M.D. (2000). Antibiotic use in animals feed and its impact on human health. Nuritiont Research Reviews, Vol.13, pp.79-299

Ben Kahla-Nakbi, A.; K., Chaieb; A., Besbes; T., Zmantar \& A., Bakhrouf, (2006). Virulence and enterobacterial repetitive intergenic consensus PCR of Vibrio alginolyticus strains isolated from Tunisian cultured gilthead sea bream and sea bass outbreaks. Veterinary Microbiology, Vol.117, pp.321-327

Boggard van den, AE. \& Stobberingh EE. (2000). Epidemiology of resistance to antibioticsLinks between animals and humans. International Journal of Antimicrobial Agents, Vol.14, pp.327-335

Bouamama, K. (2001). Mytilus galloprovincialis de la lagune de Bizerte : populations bactériennes et Biomarqueurs non spécifiques. Diplôme des études approfondies (DEA). Faculté des Sciences de Tunis, Institut des Sciences et Technologies de la Mer. Tunis, Tunisia 
Boutiba, I.; Ghozzi, R.; Jouaihia, W.; Mahjoubi, F.; Thabet, L.. Smaoui, H.; Ben Hassen, A. Hàmmamí, A.; Kechrid, A. \& Ben Redjeb, S. (2007). Résistance bactérienne aux antibiotiques en Tunisie : Données de 1999 A 2003, Revue Tunisienne d'Infectiologie, Vol. 1, pp. 5-11

Calo-Mata, P.; Arlindo, S.; Boehm. K. ; De Miguel, T. Pascoal A. \& Barros-Velazquez, J. (2007). Current application and future trends of lactic acid bacteria and their bacteriocins for biopreservation of aquatic food products. Food Bioprocess Technology, Vol.1(1), pp.43-63

Celli, J. \& Trieu-Cuot, P. (1998). Circularization of Tn916 is required for expression of the transposon-encoded transfer functions: characterization of long tetracyclineinducible transcripts reading through the attachment site. Molecular Microbiology, Vol. 28, pp.103-117

Chabbert Y.A (1982). L'antibiogramme. In : Bactériologie médicaleL. Le Miror, M. véron, (eds): Flammarion. Medecine Science. Paris, 205-212.

Chae-Woo, M.; Yun-Seok, C. \& Kye-Heon, O. (2009). Removal of pathogenic bacteria and nitrogens by Lactobacillus spp. JK-8 and JK-11. Aquaculture, Vol.287, pp.266-270

Chahad Ouissal, B.; El Bour, M.; Mraouna, R.; Abdennaceur, H. \& Boudabous, A. (2007). Preliminary selection study of potential probiotic bacteria from aquacultural areas in Tunisia. Annals of Microbiology, Vol.57 (2), pp.185-190

Chelossi, E. ; Vezzulli, L. ; Milano, A. ; Branzoni, M. ; Fabiano, M. ; Riccardi, G. \& Banat, I.M., (2003). Antibiotic resistance of benthic bacteria in fish-farm and control sediments of the Western Mediterranean. Aquaculture, Vol. 219, pp.83-97

CIESM 2004. Novel contaminants and pathogens in coastal waters. CIESM Workshop Monograph N²6, Monaco "www.ciesm.org/online/monographs/Neuchatel.pdf"

Clewell, DB., Flannagan, SE. \& Jaworsky. DD. (1995). Unconstrained bacterial promiscuity: the Tn916-Tn1545 family of conjugative transposons. Trends in Microbiology, Vol.3, pp.229-236

Comité de l'Antibiogramme de la Société Française de Microbiologie, (1996). Statement 1996 CA-SFM. Zone sizes and MIC breakpoints for non-fastidious organisms. Clinical Microbiology and Infecion, Vol.2, Suppl. 1, pp.46-49

Dellali, M., (2001). Utilisation d'indicateurs microbiologiques et biochimiques chez Ruditapes decussatus et Mytilus galloprovincialis dans la biosurveillance de la lagune de Bizerte: Validation de certains biomarqueurs. Thèse de doctorat, Faculté des Sciences de Bizerte. Tunisia

El Bour, M.; Attia El Hilli, H.; Mraouna, R. \& Ayari, W. (2001). Bacterial study of mesophilic Aeromonads distribution in shellfish. Proceeding of the fifth international conference on the Mediterranean coastal environment, MEDCOAST, pp.557- 565

Ennahar, S.; Aoude-Werner. D.; Assobhei, O. \& Hasselmann, D. (1998). Antilisterial activity of enterocin 81, a bacteriocin produced by Enterococcus faecium WHE 81 isolated from cheese, Journal of Applied Microbiology, Vol.85, pp.521-526

Franz, CMAP; van Belkum, MJ.; Holzapfel, WH; Abriouel, H. \& Galvez, A. (2007). Diversity of Enterococcal bacteriocins and their grouping in a new classification scheme. FEMS Microbiology Review, Vol.31, pp.293-310

Fuller, R. (1989). Probiotics in man and animals. Journal of Applied Bacteriology, Vol. 66, pp.365-378 
Giraffa, G. (1995). Enterococcal bacteriocins: their potential as anti-Listeria factors in dairy technology. Food Microbe, Vol.12, pp.291-299

Gismondo, M.R.; Drago, L.; Lombardi, A. (1999). Review of probiotics available to modify gastrointestinal flora. International Journal of Antimicrobial Agents, Vol. 12, pp.287292

Gram, L.; Melchiorsen, J.; Spanggaard, B.; Huber, I. \& Nielsen, T.F. (1999). Inhibition of Vibrio anguillarum by Pseudomonas fluorescens $\mathrm{AH} 2$, a possible probiotic treatment of fish. Applied and Environmental Microbiology, Vol.65 (3), pp.969-973

Gullian, M.; Thompson, F. \& Rodriguez, J. (2004). Selection of probiotic bacteria and study of their immunostimulatory effect in Penaeus vannamei. Aquaculture, Vol.233, pp.1-14

Huycke, MM.; Sahm, DF. \& Gilmore, MS. (1998). Multiple-drug resistant enterococci: the nature of the problem and an agenda for the future. Emerging Infectious Diseases, Vol.4(2), pp.239-249

Irianto, A. \& Austin, B. (2002a). Probiotics in aquaculture. Journal of Fish Diseases, Vol.25, pp.633-642

Irianto, A. \& Austin, B. (2002b). Use of probiotics to control furunculosis in rainbow trout, Oncorhynchus mykiss (Walbaum). Journal of Fish Diseases, Vol.25, pp.333-342

Itami, T.; Asano, M.; Tokushige, K.; Kubono, K.; Nakagawa, A.; Noboru, T.; Nishimura, H.; Maeda, M.; Kondo, M. \& Takahashi, Y. (1998). Enhancement of disease resistance of kuruma shrimp, Penaeus japonicus, after oral administration of peptidoglycan derived from Bifidobacterium thermophilum. Aquaculture, Vol.164, pp.277-288

Murray, BE. (1998). Diversity among multidrug-resistant enterococci. Emerging Infectious Diseases, Vol. 4, pp.37-47

Kato, T.; Matsuda, T.; Ogawa, E.; Ogawa, H.; Kato, H.; Doi, U. \& Nakamura, R. (1994). Plantaricin-149, a bacteriocin produced by Lactobacillus pluntarum NRIC 149. Journal of Fermentution and Bioengineering, Vol.77, pp.277-282

Kuhn, I.; Iversen, A.; Burman, L.G.; Olsson-Liljequist, B.; Franklin, A.; Finn, M.; Aarestrup, F.; Seyfarth, A.M.; Blanch, A.R., Taylor, H.; Caplin, J.; Moreno, M.A.; Dominguez, L. \& Mollby, R. (2000). Epidemiology and ecology of enterococci, with special reference to antibiotic resistant strains, in animals, humans and the environment. Example of an ongoing project within the European research programme. International Journal of Antimicrobial Agents. Vol.14, pp.337-342

Lategan, M.J. \& Gibson, L.F. (2003). Antagonistic activity of Aeromonas media strain A199 against Saprolegnia sp., an opportunistic pathogen of the eel, Anguilla australis Richardson. Journal of Fish Diseases, Vol.26, pp.147-153

Lategan, M.J.; Torpy, F.R. \& Gibson, L.F. (2004a). Biocontrol of saprolegniosis in silver perch Bidyanus bidyanus (Mitchell) by Aeromonas media strain A199. Aquaculture, Vol.235, pp.77-88

Lategan, M.J.; Torpy, F.R. \& Gibson, L.F. (2004b). Control of saprolegniosis in the eel Anguilla australis Richardson, by Aeromonas media strain A199. Aquaculture, Vol.240, pp.19-27

Laukova, A.; M., Marekova \& P. Javorsky. (1993). Detection and antimicrobial spectrum of a bacteriocin like substances produced by Enterococcus faecium CCM4231. J. Letters in Applied Microbiology, Vol.16, pp.257-260 
Lukàsova, J. \& Sustàckovà, A. (2003). Enterococci and Antibiotic Resistance: Review Article. Acta. Veterinaria Brno., Vol.72, pp.315-323

Marcinek, H.; Wirth, R.; Muscholl-Silberhorn, A. \& Gauer, M. (1998). Enterococcus faecalis gene transfer under natural conditions in municipal sewage water treatment plants. Applied and Environmental Microbiology, Vol.64, pp.626-632

Mauguin, S. \& Novel, G. (1994). Characterization of lactic acid bacteria isolated from seafood. Journal of Applied Bacteriology, Vol.76, pp.616-625

Marra, D. \& Scott. JR. (1999). Regulation of excision of the conjugative transposon Tn916. Molecular Microbiology, Vol.31, pp.609-621

Matyar, F. (2007). Distribution and antimicrobial multiresistance in Gram-negative bacteria isolated from Turkish sea bass (Dicentrarchus labrax L., 1781) farm. Annals of Microbiology, Vol.57, pp.35-38

Nogami, K. \& Maeda, M. (1992). Bacteria as biocontrol agents for rearing larvae of the Crab Portunus trituberculatus. Canadian Journal of Fish. and Aquatic Sciences, pp.2373-2376

Ramirez, R.F. \& Dixon, B.A. (2003). Enzyme production by obligate intestinal anaerobic bacteria isolated from Oscars (Astronotus ocellatus), angelfish (Pterophyllum scalare) and southern flounder (Paralichthys lethostigma). Aquaculture, Vol.227, pp.417-426

Rengpipat, S.; Phianphak, W.; Piyatiratitivorakul, S. \& Menasveta, P. (1998). Effects of a probiotic bacterium on black tiger shrimp Penaeus monodon survival and growth. Aquaculture Vol.167, pp.301-313

Rengpipat, S., Rueangruklikhit, T. \& Piyatiratitivorakul, S. (2008). Evaluations of lactic acid bacteria as probiotics for juvenile sea bass Lates calcarifer. Aquaculture Research, Vol.39, pp.134-143

Rezgui, I. (2010). Etude de l'antibioresistance chez deux espèces de poisons aquacoles en Tunisie: le loup (Dicentrarchus labrax) et la daurade (Sparus aurata). Master of Biology. University of Sciences of Tunis. Institut des Sciences et Technologies de la Mer. Tunis, Tunisia

Rice, E.W.; Messer, J.W.; Johnson, C.H. \& Reasoner, D.J. (1995). Occurrence of high-level aminoglycoside resistance in environmental isolates of enterococci. Applied and Environmental Microbiology. Vol.61, pp.374-376

Rico-Mora, R.; Voltolina, D. \& Villaescusa-Celaya, J.A. (1998). Biological control of Vibrio alginolyticus in Skeletonema costatum (Bacillariophyceae) cultures. Aquacultural Engineering Vol.19, pp.1-6

Rigos, G.; Nengas, I.; Alexis, M. \& Troisi, G. (2004). Potential drug (oxytetracycline \& oxolinic acid) pollution from Mediterranean sparid fish farms. Aquatic Toxicology, Vol.69, pp.281-288

Rigos, G. \& Troisi, G. (2005). Antibacterial agents in Mediterranean finfish farming: a synopsis of drug pharmacokinetics in important euryhaline fish species and possible environmental implications. Reviews in Fish Biology and Fisheries, Vol.15, pp.53-73

Ringo, E. (1999). Lactic acid bacteria in fish: antibacterial effect against fish pathogens.In effects of Anti nutrients on the Nutritional Value of Legume Diets, Vol.8, ed. 
Krogdahl, Mathiesen, SD. And Pryme, I. COST 98. 70-75, Luxembourg: EEC Publication.

Ringø, E. \& Gatesoupe, F.-J. (1998). Lactic acid bacteria in fish: a review. Aquaculture, Vol.160, pp.177-203

Ringo, E. (2008). The ability of Carnobacteria isolated from fish intestine to inhibit growth of fish pathogenic bacteria: a screening study. Aquaculture Research, Vol.39, pp.171-180

Salminen, S.; Ouwehand, A.; Benno, Y. \& Lee, Y.K. (1999). Probiotics: how should they be defined. Trends in Food Science and Technology, Vol.10, pp.107-110

Smith, P.; Hiney, M. \& Samuelson, O. (1994). Bacterialresistance to antimicrobial agents used in fish farming: a critical evaluation of method and meaning. Annual Review of Fish Diseases, Vol.4, pp.273-313

Smith, V.J.; Brown, J.H. \& Hauton, C. (2003). Immunostimulation in crustaceans: does it really protect against infection?. Fish and Shellfish Immunology, Vol.15, pp.71-90

Sorum, H. (1998). Mobile drug resistance genes among fish bacteria. APMIS Suppl., Vol.106, pp.74-76

Sorum, H. (1999). Antibiotic resistance in aquaculture. Acta Veterinaria Scandinavica Suppl., Vol.92, pp.29-36

Spanggaard, B.; Huber, I., Nielsen, J.; Sick. E.B.; Pipper, C.B.; Martinussen, T.; Slierendrecht, W.J. \& Gram, L. (2001). The probiotic potential against vibriosis of the indigenous microflora of rainbow trout. Environmental Microbiology, Vol.3(12), pp.755-765

Vaseeharan, B.; Lin, J. \& Ramasamy, P. (2004). Effect of probiotics, antibiotic sensitivity, pathogenicity, and plasmid profiles of Listonella anguillarum like bacteria isolated from Penaeus monodon culture systems. Aquaculture, Vol.241, pp.77-91

Verschuere, L. ; Rombaut, G. ; Huys, G. ; Dhont, J. ; Sorgeloos, P. \& Verstraete, W. (1999). Microbial control of the culture of Artemia juveniles through preemptive colonization by selected bacterial strains. Applied and Environmental Microbiology, Vol.65, pp.2527-2533

Verschuere, L.; Rombaut, G.; Sorgeloos, P. \& Verstraete, W. (2000a). Probiotic bacteria as biological control agents in aquaculture. Microbiology and Molecular Biology Review, Vol.64, pp.655-671

Verschuere, L.; Heang, H.; Criel, G.; Sorgeloos, P. \& Verstraete,W. (2000b). Selected bacterial strains protect Artemia spp. from the pathogenic effects of Vibrio proteolyticus CW8T2. Applied and Environmental Microbiology, Vol.66(3), pp.1139-1146

Vijayabaskar, P. \& Somasundaram, S. T. (2008). Isolation of bacteriocin producing lactic acid bacteria from fish gut and probiotic activity against common fresh water fish pathogen Aeromonas hydrophila. Biotechnology, Vol.7, pp.124-128

Vijayan, K.K.; Bright Singh, I.S.; Jayaprakash, N.S.; Alavandi, S.V.; Somnath Pai, S., Preetha, R.; Rajan, J.J.S. \& Santiago, T.C. (2006). A brackish water isolate of Pseudomonas PS102 , a potential antagonistic bacterium against pathogenic vibrios in penaeid and non-penaeid rearing systems. Aquaculture, Vol.251, pp.192-200

Yan, L.; Boyd, K.G. \& Burgess, J.G. (2002). Surface attachment induced production of antimicrobial compounds by marine epiphytic bacteria using modified roller bottle cultivation. Marine Biotechnology, Vol.4, pp.356-366 
Zorrilla, I.; M., Chabrillón; S., Arijo; P., Díaz Rosales; E., Martínez-Manzanares; M.C., Balebona \& M.A., Moriñigo, (2003). Bacteria recovered from diseased cultured gilthead sea bream (Sparus aurata L.) in southwestern Spain. Aquaculture, Vol.218, pp.11-20 


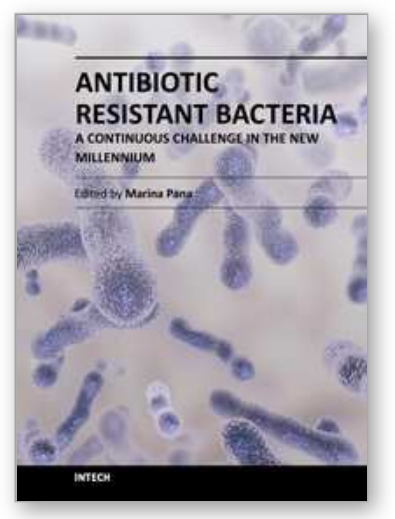

\section{Antibiotic Resistant Bacteria - A Continuous Challenge in the New Millennium}

Edited by Dr. Marina Pana

ISBN 978-953-51-0472-8

Hard cover, 576 pages

Publisher InTech

Published online 04, April, 2012

Published in print edition April, 2012

Antibiotic-resistant bacterial strains remain a major global threat, despite the prevention, diagnosis and antibiotherapy, which have improved considerably. In this thematic issue, the scientists present their results of accomplished studies, in order to provide an updated overview of scientific information and also, to exchange views on new strategies for interventions in antibiotic-resistant bacterial strains cases and outbreaks. As a consequence, the recently developed techniques in this field will contribute to a considerable progress in medical research.

\section{How to reference}

In order to correctly reference this scholarly work, feel free to copy and paste the following:

Ouissal Chahad Bourouni, Monia El Bour, Pilar Calo-Mata and Jorge Barros-Velàzquez (2012). Antimicrobial Resistance and Potential Probiotic Application of Enterococcus spp. in Sea Bass and Sea Bream Aquaculture, Antibiotic Resistant Bacteria - A Continuous Challenge in the New Millennium, Dr. Marina Pana (Ed.), ISBN: 978-953-51-0472-8, InTech, Available from: http://www.intechopen.com/books/antibiotic-resistant-bacteria-acontinuous-challenge-in-the-new-millennium/antimicrobial-resistance-and-potential-probiotic-application-ofenterococcus-spp-in-sea-bass-and-sea

\section{INTECH}

open science | open minds

\section{InTech Europe}

University Campus STeP Ri

Slavka Krautzeka 83/A

51000 Rijeka, Croatia

Phone: +385 (51) 770447

Fax: +385 (51) 686166

www.intechopen.com

\section{InTech China}

Unit 405, Office Block, Hotel Equatorial Shanghai

No.65, Yan An Road (West), Shanghai, 200040, China

中国上海市延安西路65号上海国际贵都大饭店办公楼405单元

Phone: $+86-21-62489820$

Fax: +86-21-62489821 
(C) 2012 The Author(s). Licensee IntechOpen. This is an open access article distributed under the terms of the Creative Commons Attribution 3.0 License, which permits unrestricted use, distribution, and reproduction in any medium, provided the original work is properly cited. 